TABLE 1. Cardiac leiomyosarcoma metastasizing to the brain: Literature review

\begin{tabular}{|c|c|c|c|c|c|c|c|c|}
\hline References & $\begin{array}{c}\text { Age } \\
(y) / \text { sex }\end{array}$ & $\begin{array}{c}\text { Initial } \\
\text { symptoms }\end{array}$ & $\begin{array}{c}\text { Primary } \\
\text { tumor }\end{array}$ & Surgical procedure & Adjuvant therapy & $\begin{array}{c}\text { Brain } \\
\text { metastasis }\end{array}$ & $\begin{array}{c}\text { Other } \\
\text { metastasis }\end{array}$ & $\begin{array}{c}\text { Survival } \\
\text { time } \\
\end{array}$ \\
\hline $\begin{array}{l}\text { Babatasi and } \\
\text { coworkers, }{ }^{3} \\
1998\end{array}$ & 47 , male & $\begin{array}{l}\text { Weight loss, } \\
\text { pulmonary } \\
\text { edema }\end{array}$ & Left atrium & $\begin{array}{l}\text { Resection of the left } \\
\text { atrial mass } \\
\text { orthotopic } \\
\text { heart } \\
\text { transplantation } \\
\text { after } 6 \text { mo }\end{array}$ & None & $\begin{array}{l}15 \text { mo } \\
\text { later }\end{array}$ & Liver, bone & $15 \mathrm{mo}$ \\
\hline $\begin{array}{l}\text { Thomas and } \\
\text { coworkers, } \\
1992\end{array}$ & 37 , male & $\begin{array}{l}\text { Polyarthralgia, } \\
\text { fever, dyspnea }\end{array}$ & Left atrium & $\begin{array}{l}\text { Resection of the } \\
\text { atrial mass, } \\
\text { resection } \\
\text { of brain } \\
\text { metastasis, } \\
\text { partial bowel } \\
\text { resection }\end{array}$ & $\begin{array}{l}\text { Mediastinal } \\
\text { radiotherapy plus } \\
\text { Chemotherapy, } \\
\text { (whole-brain and } \\
\text { local boost) }\end{array}$ & $\begin{array}{l}14 \text { mo } \\
\text { later }\end{array}$ & $\begin{array}{l}17 \text { mo later, } \\
\text { multiple } \\
\text { sites }\end{array}$ & $17 \mathrm{mo}$ \\
\hline Cohen, ${ }^{5} 1969$ & 41 , male & $\begin{array}{l}\text { Hemoptysis, } \\
\text { chest pain, } \\
\text { headache }\end{array}$ & $\begin{array}{l}\text { Right and left } \\
\text { atrium plus } \\
\text { bowel }\end{array}$ & $\begin{array}{l}\text { Resection of the } \\
\text { cardiac } \\
\text { tumor, cardiac } \\
\text { reoperation }\end{array}$ & None & $\begin{array}{l}\text { Autopsy } \\
\text { finding }\end{array}$ & $\begin{array}{l}\text { Autopsy } \\
\text { finding, } \\
\text { multiple } \\
\text { sites }\end{array}$ & $17 \mathrm{mo}$ \\
\hline
\end{tabular}

Our patient is unique with regard to the concomitant manifestation of the cerebral and cardiac leiomyosarcomas. Most likely, the cerebral manifestation should be regarded as a metastasis; the immunohistochemical profiles and the clinical history, however, also allow different interpretations.

The best available therapy for undifferentiated leiomyosarcoma consists of early detection and radical surgical removal. Although the cardiac tumor in our patient showed no relapse after complete removal, the cerebral tumor recurred several times. The repeated craniotomies within short intervals can be discussed controversially. Nevertheless, because the patient was asymptomatic apart from occasional seizures, we decided to offer him these options as live-saving procedures.

Concomitant cardiac and cranial leiomyosarcoma seems to be particularly aggressive, and only diligent follow-up examinations and early surgical intervention will make long- term survival possible. There is a need for more efficacious adjuvant therapy.

\section{References}

1. Antunes MJ, Vanderdonck KM, Andrade CM, Rebelo LS. Primary cardiac leiomyosarcomas. Ann Thorac Surg. 1991;51:999-1001.

2. Butany J, Nair V, Naseemuddin A, Nair GM, Catton C, Yau T. Cardiac tumors: diagnosis and management. Lancet Oncol. 2005;6:219-28.

3. Babatasi G, Massetti D, Agostini F, Galateau F, Le Page O, Saloux E, et al. Leiomyosarcomas of the heart and great vessels. Ann Cardiol Angiol. 1998; 47:451-8.

4. Thomas CR Jr, Johnson GW Jr, Stoddard MF, Clifford S. Primary malignant cardiac tumors: update 1992. Med Pediatr Oncol. 1992;20:519-31.

5. Cohen ML. Intracardiac leiomyosarcoma. N Y State J Med. 1969;69:1767-72.

6. Straus R, Merliss R. Primary tumor of the heart. Arch Pathol Lab Med. 1945;39: 74-8.

7. Espat NJ, Bilsky M, Lewis JJ, Leung D, Brennan MF. Soft tissue sarcoma brain metastases: prevalence in a cohort of 3829 patients. Cancer. 2002;94:2706-11.

8. Paulus W, Slowik F, Jellinger K. Primary intracranial sarcomas: histopathological features of 19 cases. Histopathology. 1991;18:395-402.

\title{
Cardiac echinococcosis of the interventricular septum in early childhood: Report of two cases
}

T. Mohsen, MD, FRCS, N. El Beharry, MD, T. Maree, MD, and E. S. Akl, MD, Cairo, Egypt

\author{
From the Department of Cardiothoracic Surgery, Kasr El Aini Hospital, Cairo \\ University, Cairo, Egypt. \\ Received for publication April 2, 2008; accepted for publication April 16, 2008. \\ Address for reprints: T. Mohsen, MD, FRCS, Kasr El Aini Hospital, Cairo University \\ Cardiothoracic Surgery, Villa 23 street 262 New Maadi, Cairo11431 Egypt (E-mail: \\ tmohsen_2000@yahoo.com). \\ J Thorac Cardiovasc Surg 2009;137:e14-6 \\ 0022-5223/\$36.00 \\ Copyright (c) 2009 by The American Association for Thoracic Surgery \\ doi:10.1016/j.jtcvs.2008.04.008
}

Echinococcosis has a low endemicity in Egypt. However, in some governorates it presents a public health concern with an incidence ranging from 0.8 to 2.6 per $100,000 .^{1}$ Cardiac infestation is very uncommon, accounting for $0.5 \%$ to $2 \%$ of all hydatid infestations. ${ }^{2}$ We present 2 cases of hydatid cysts of the interventricular septum in early childhood. 


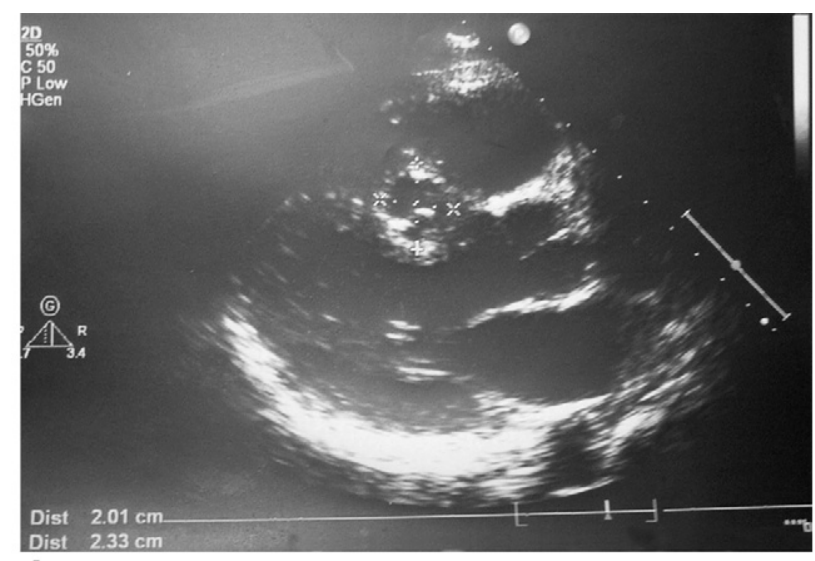

A

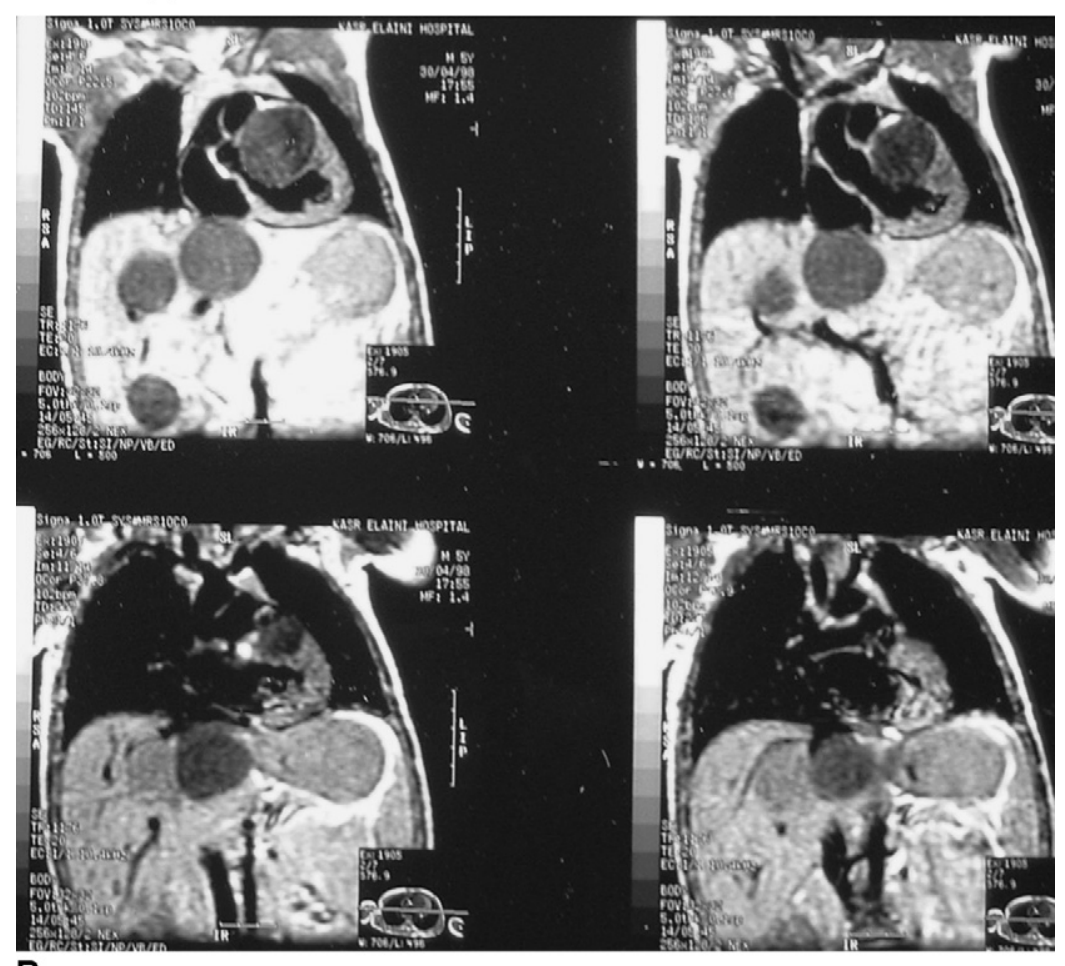

B

FIGURE 1. A, Echocardiogram showing $2 \times 2.33-\mathrm{cm}$ interventricular hydatid cyst. B, Magnetic resonance images showing mulitivesicular hydatid cysts.

\section{CLINICAL SUMMARIES}

PATIENT 1. A 5-year-old boy had had progressive dyspnea over the past 4 months and easy fatigability. The results of routine examinations were within normal limits. Echocardiography revealed an interventricular cyst $2.1 \times$ $2.3 \mathrm{~cm}$.

PATIENT 2. A 4-year-old boy had palpitations and progressive dyspnea over the past 6 months, with two episodes of ventricular tachyarrhythmias. Results of routine examination and laboratory studies were within normal limits. Echocardiography revealed a large cyst, $3 \times 3 \mathrm{~cm}$, in the interventricular septum.
Magnetic resonant imaging, done for both patients. confirmed the diagnosis and showed concomitant hepatic infestation in the second patient (Figure 1).

\section{SURGICAL TECHNIQUE}

Standard median sternotomy was used, with cardiopulmonary bypass and warm blood cardioplegic arrest. The interventricular septum was reached through the tricuspid valve. A bulge was noted in both cases near the outflow tract of the right ventricle. The cysts were first aspirated and the covering layer of the septal myocardium was dissected until the cysts' walls were reached. They could then be removed 

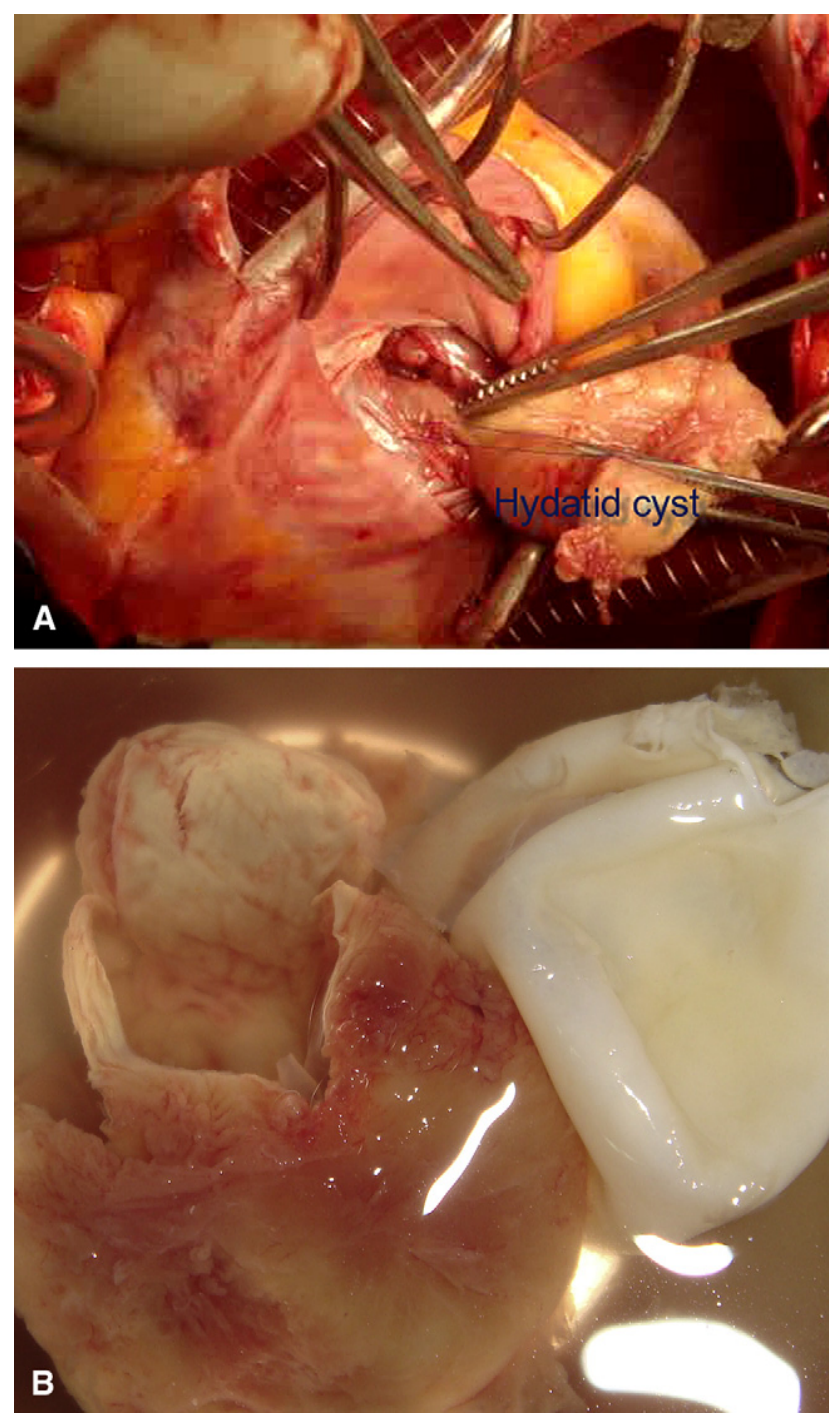

FIGURE 2. A and B, Operative photographs of hydatid cysts.

(Figure 2). In the first patient a ventricular septal defect was created, and this was closed with a Dacron patch. In the second patient the remaining cavity was suture closed. Both patients had uneventful postoperative recoveries and were discharged on days 7 and 10 postoperatively. Three months later the second patient underwent laparotomy for removal of hepatic cysts.

\section{COMMENT}

In this report, we present 2 particularly interesting cases of hydatid cyst of the interventricular septum at a rare age of presentation. Moreover, 1 of these patients had multivesicular cysts. Because the cyst takes 1 to 5 years to grow, the usual presentation of hydatid disease of the heart occurs at or over 20 years of age. ${ }^{3,4}$ Echinococcosis is a human parasitic disease most commonly caused by the larval stage of Echinococcus granulosus. As a rule, lung cysts and heart echinococcosis occur less often than hepatic cysts. The most frequent location in the heart is the ventricular myocardium. ${ }^{5}$ Cardiac echinococcal cysts rarely involve the interventricular septum. Presentation varies according to the location in the septum; therefore, compression involving the atrioventricular conduction pathway may lead to variable arrhythmias or obstruction to the ventricular outflow tract. However, the most dangerous complication is cyst perforation, which has a frequency between $25 \%$ and $40 \%$. After cyst perforation, three quarters of the patients die of septic shock or embolic complications.

Diagnosis of cardiac hydatid cyst is simple, reliable, and sensitive when transthoracic echocardiography is used. ${ }^{5}$ However, computed tomographic scan and magnetic resonance imaging are complementary tools to rule out mutivesicular cysts.

In this report, we used standard median sternotomy with cardiopulmonary bypass. The septum was reached through the tricuspid valve, and initially the content was aspirated and a crystal rock fluid was obtained. Sterilization before enucleation with different agents has been mentioned in the literature. In this report, we did not use any sterilizing agent but depended on complete enucleation of the cyst; in 1 case, we had to create a ventricular septal defect to achieve this. Albendazole was routinely given for 6 months after the operation.

In conclusion, cardiac echinococcosis is a rare disease. We report 2 cases of cardiac echinococcosis in childhood, 1 of which was multivesicular. Follow-up extends for 9 years without recurrence.

\section{References}

1. Kandeel A, Ahmed ES, Helmy H, El Setouhy M, Craig PS, Ramzy RMR. A retrospective hospital study of human cystic echinococcosis in Egypt. Available at www.emro.who.int/Publications/Emhj/1003/A retrospective.htm.

2. Miralles A, Bracamonte L, Pavie A. Cardiac echinococcosis: surgical treatment and results. J Thorac Cardiovasc Surg. 1994;107:184-90.

3. Pérez Gómes F, Durán H, Tamames S, Perrote JL, Blanes A. Cardiac echinococcosis: clinical picture and complications. Br Heart J. 1973;35:1326-31.

4. Oliver JM, Sotillo JF, Domínguez FJ, López de Sá E, Calvo L, Salvador A, et al. Two-dimensional echocardiographic features of echinococcosis of the heart and great blood vessels. Clinical and surgical implications. Circulation. 1988;78: 327-37.

5. Di Bello R, Menendez H. Intracardiac rupture of hydatid cyst of the heart: a study based on three personal observations and 101 cases in the world literature. $\mathrm{Circu}$ lation. 1963;27:366-74. 